\title{
Research on Correlation between learning style, learning strategy of students and English Teaching Effect
}

\author{
Guan Jian \\ School of Foreign Languages,Jilin Agricultural University, Changchun, Jilin 130118
}

\begin{abstract}
The objective of the research is to investigate if the learning style and learning strategy of students relates to English achievement. The writer tries investigating the correlation between overall learning style, learning strategy and English learning level. The research results indicate that the students generally use compensation strategy, cognitive strategy, metacognitive strategy and social strategy, and seldomly use affective strategy.
\end{abstract}

Key words: perception learning style, learning strategy, English level

\section{INTRODUCTION}

The research on learning style can date back to 1970s. The theory of learning style is how the individuals summarize learning under different learning conditions. It is the research on individual difference, and the researchers firstly observed individual difference and performance difference. The researches indicate that the students and teachers realize the importance of learning style and learning strategy. Different learning styles and learning strategies have great influence on English learning achievements, and how to perceive style preference influences the application of learning strategies. The application of learning strategies for students should combine different learning styles. Learning strategy training is an important way to improve learning efficiency of students. But it aims at many students, so effective learning strategy and learning style can improve the training effect of teachers.

In China, most researches on learning style and learning strategy are separate. In order to observe the influence of learning strategy, learning style and internal factors on academic record, the paper makes empirical research on the relationship between the application of perceptive learning style and learning strategy and English achievement.

\section{RESEARCH DESIGN AND IMPLEMENTATION}

\section{A. 2.1 Objective and hypothesis}

In order to study English learning style and learning strategy of students, the paper analyzes the learning style and learning strategy causing the change of learning achievement, and proposes some opinions and suggestions to improve teaching and learning efficiency of teachers and students.
The required information of the research includes the application of learning style preference and learning strategy, the relationship between English learning achievement of different perceptive learning styles and learning strategies, and the relationship between perceptive learning style, learning strategy and English achievement of students.

Based on referring to the literatures and actual survey, the writer proposes the following hypotheses.

Hypothesis 1: there is close relationship between visual learning style, learning strategy and student achievement.

Hypothesis 2: there is close relationship between auditory learning style, learning strategy and student achievement.

Hypothesis 3: there is close relationship between tactile learning style, learning strategy and student achievement.

\section{B. Sample selection and tools}

The research selects 100 middle school students from second-year junior high school in four schools. The reason why the second-year junior high school students are selected is that they have adapted to the life of middle school and formed their ways of learning English, so they can have their learning styles and learning strategies.

The research tools for the research are questionnaires of learning perception style preference and scales of language learning strategy, and English learning achievement selects the final examination grade of students.

\section{Scale of language learning strategy}

SILL aims at self-survey of English learners, and was firstly designed by Oxford ( 1990 ). SILL includes memory strategy, cognitive strategy, compensation strategy, metacognitive strategy, emotion strategy and social strategy. In the research, it includes five parts.

Problem 1-6: cognitive strategy for comprehending and generating language.

(1) Problem 7-12: compensation strategy for overcoming defects of other available information learning language.

(2) Problem 13-18: metacognitive strategy for guiding learning process.

(3) Problem 19-24 for adjusting the emotion, motivation and attitude of students.

(5) Problem 25-30: social strategy for improving interaction of learning and others. 


\section{Research process}

The questionnaires are issued to students. The students need to fill in their names, sexes, date and schools. The questionnaires of higher vocational college students only aims at investigating direct correlation between their English learning styles, learning strategy and English achievement. The answers have no the difference between right and wrong, which makes them answer the questionnaires according to the actual conditions. And the problems in the questionnaires are introduced simply. For each question, the students are required to write a number

$(1,2,3,4$ or 5$)$. In the process, the students have to discuss with other students. If the question is difficult to be comprehended, the students can turn to the teachers, and it takes about 30 or 40 minutes to answer the questionnaires.

English achievement selects the final examination grade in 2011. The collected data includes questionnaire data and final examination grade of students, and the data receives SPSS analysis.

\section{DATA COLLECTION AND ANALYSIS OF EMPIRICAL RESULTS}

\section{A. Data set}

100 students are selected. After investigation, 9 effective questionnaires are submitted. For 96 students, there were 55 boys and 41 girls.

PLSPS and SILL data of participants can be achieved from questionnaires, and the test scores are provided by the teachers.

\section{B. Result analysis}

The above method and process is used to achieve the relevant data of perceptive learning styles, learning strategy and English achievement. After analyzing the data, the writer masters the perceptive learning style preference and the tendency of using learning strategies, and the academic score of students by using different perceptive learning styles and learning strategies. In the process, the writer collects the teaching styles of teachers. Lastly, according to the above analysis, the paper proposes the relationship between perceptual learning style, learning strategy and academic score of students.

(1) Reliability of questionnaire

The objective analysis results of questionnaire reliability are shown in Table 1 .

Table 1 Data reliability analysis (alpha)

\begin{tabular}{|c|c|c|c|}
\hline \multirow{2}{*}{} & \multicolumn{2}{|c|}{ Credibility } \\
\cline { 2 - 4 } & Sample number & $\begin{array}{l}\text { Question } \\
\text { number }\end{array}$ & $\begin{array}{c}\text { Alpha } \\
\text { score }\end{array}$ \\
\hline Perceptual learning style & 96.0 & 24 & 0.7739 \\
\hline Learning strategy & 96.0 & 30 & 0.8686 \\
\hline
\end{tabular}

From the table, we can see that alpha score of perceptual learning style is 0.7739 , and that of learning strategy is 0.8686 . Therefore, the reliability of the questionnaires is high, and can be used for the research.

(2) General trend of perceptual learning style preference

The investigation results of perceptual learning style preference receive SPSS calculation, and the results are as follows.

Table 2 Mean of perceptual learning style preference

\begin{tabular}{|l|l|r|r|r|r|}
\hline Style & Maximum & Minimum & Mean & $\begin{array}{l}\text { Standard } \\
\text { deviation }\end{array}$ & Rank \\
\hline $\begin{array}{l}\text { Vision } \\
(1-8)\end{array}$ & 1.00 & 5.00 & 3.4284 & 1.05770 & 1 \\
\hline $\begin{array}{l}\text { Audition } \\
(9-16)\end{array}$ & 1.00 & 5.00 & 3.0677 & 1.03931 & 3 \\
\hline $\begin{array}{l}\text { Tactile } \\
(17-24)\end{array}$ & 1.00 & 5.00 & 3.3841 & 1.14165 & 2 \\
\hline
\end{tabular}

From the above table, we can see that the visual style is the most popular learning style (3.4284), and tactile learning style ( 3.3841 ) and auditory learning way (3.0677) are secondary. The difference between visual learning style and tactile learning style is 0.0443 , and the difference between visual learning style and tactile learning style is 0.3164 .

The teaching styles of teachers also have influence on learning style preference of students, so there is the research on teaching styles of teachers.

Table 3 Teaching styles of teachers

\begin{tabular}{|c|c|c|c|c|}
\hline & $\begin{array}{l}\text { Mini } \\
\text { mum }\end{array}$ & $\begin{array}{l}\text { Max } \\
\text { imum }\end{array}$ & Mean & $\begin{array}{l}\text { Standa } \\
\text { rd } \\
\text { deviation }\end{array}$ \\
\hline VT & 1.00 & 5.00 & 3.2854 & $\begin{array}{ll} & 1.0887\end{array}$ \\
\hline AT & 1.00 & 5.00 & 3.4479 & $2^{1.0346}$ \\
\hline HT & 1.00 & 5.00 & 3.3854 & $\begin{array}{ll} & 1.1897 \\
0 & \end{array}$ \\
\hline
\end{tabular}

Note: VT, visual teaching style. AT, auditory teaching style, HT, tactile teaching style.

The comparison indicates that it is easy to find different learning style preferences of teachers and students. The most popular teaching style is auditory teaching style, but the best learning way of students is visual learning style.

(3) General trend of learning strategy

The results of calculating learning strategies of students are shown in the following table 4. 
Table 4 Statistical analysis of learning strategy selection of students

\begin{tabular}{|l|c|c|c|c|}
\hline Strategy & Minimum & Maximu & Mean & $\begin{array}{c}\text { Standard } \\
\text { deviation }\end{array}$ \\
\hline $\begin{array}{c}\text { Cognitive strategy } \\
(1-6)\end{array}$ & 1.00 & 5.00 & 3.4201 & 1.07001 \\
\hline $\begin{array}{c}\text { Compensation } \\
\text { strategy (7-12) }\end{array}$ & 1.00 & 5.00 & 3.5191 & 1.05319 \\
$\begin{array}{c}\text { Metacognitive } \\
\text { strategy (13-18) }\end{array}$ & 1.00 & 5.00 & 3.3073 & 1.03723 \\
\hline $\begin{array}{l}\text { Emotion strategy } \\
(19-24)\end{array}$ & 1.00 & 5.00 & 2.9861 & 1.15110 \\
\hline $\begin{array}{l}\text { Social strategy (25- } \\
\text { 30) }\end{array}$ & 1.00 & 5.00 & 3.2274 & 1.12304 \\
\hline
\end{tabular}

From the above table, we can see that compensation strategy (3.5191) and cognitive strategy are the most common, metacognitive strategy (3.3073) and social strategy (3.2274) are secondary, and emotion strategy (2.9861) is the last.

\section{Perceptual learning style of students}

In order to find the perceptual learning style influencing English achievement of students, students are classified according to perceptual style preferences. Each student answers 24 questions in PLSPS questionnaire which involve three different perceptual learning styles. The preceding eight questions relate to visual learning style preference, and the following eight questions relate to auditory learning style preference, and the other questions relate to tactile learning style preference. In order to make calculation easy, the scores of eight questions of each preference are added to get three groups of scores. So each student has three groups of scores. And the learning styles of students are compared according to scores, and the results are shown in the following table.

Table 5 Distribution of students with different learning styles

\begin{tabular}{|l|l|l|}
\hline Style & Number & Proportion \\
\hline Vision & 22 & $22.92 \%$ \\
\hline Audition & 18 & $18.75 \%$ \\
\hline Touch & 36 & $37.50 \%$ \\
\hline Others & 20 & $20.83 \%$ \\
\hline
\end{tabular}

The examination grade of students is analyzed, which includes total score, listening score, reading score, words score and writing score. The scores of students with different learning styles are as follows.

Table 6 Average score of students with different perceptual learning style

\begin{tabular}{|c|c|c|c|c|c|}
\hline Style & Total score & Listening & Reading & Words & \multicolumn{2}{|c|}{ Writin } \\
\hline Vision & 72.676 & 18.66317 & 14.34803 & 8.147415 & \multicolumn{2}{|c|}{31.185} \\
\hline Audition & 70.45505 & 18.76366 & 12.83385 & 7.625367 & 17 \\
\hline Tactile & 70.02414 & 17.74726 & 12.96032 & 8.131227 & $2^{31.516}$ \\
\hline
\end{tabular}

From the above table, we can see that the score of the students with learning style of visual preference is better, and the total score is (72.676) in which the reading score

(14.34803) and words score (8.147415) is the highest. The students preferring to auditory learning strategy has the highest listening score (18.76366). For the students with tactile learning style, the writing score (31.51661) is the most excellent. The average score of students with visual style is the highest. The listening score of students with visual style and auditory style are better than that of students with tactile style. The average reading score of students with auditory and tactile style is lower than the students with visual style. The average score of students with visual and tactile style is higher than that of students with auditory style.

\section{Application of learning strategies of students with different perceptual learning styles}

The students are classified according to the perceptual learning style preference, which describes the application of learning strategies of students with different perceptual learning styles. The average scores of each strategy are calculated, and the results are as follows. 
Table 7 Application of learning strategies of students with different perceptual learning styles

\begin{tabular}{|l|l|c|c|c|c|c|}
\hline \multicolumn{2}{|c|}{} & $\begin{array}{c}\text { Cognitive } \\
\text { strategy }\end{array}$ & $\begin{array}{c}\text { Compensation } \\
\text { strategy }\end{array}$ & $\begin{array}{c}\text { Metacognitiv } \\
\text { e strategy }\end{array}$ & $\begin{array}{c}\text { Emotion } \\
\text { strategy }\end{array}$ & $\begin{array}{c}\text { Social } \\
\text { strategy }\end{array}$ \\
\hline Vision & Score & 3.4091 & 3.5152 & 3.3636 & 3.0076 & 3.3864 \\
\hline Audition & Score & 3.3981 & 3.6018 & 3.0833 & 2.8981 & 3.1111 \\
\hline Tactile & Score & 3.4907 & 3.5972 & 3.4259 & 3.0463 & 3.3472 \\
\hline
\end{tabular}

From the above table, we can see that the score of compensation strategy is the highest $(3.5152,3.60183$ and 3.5972), and the score of emotion strategy is the lowest $(3.0076,2.8981$ and 3.0463 ). The result is consistent with the trend of learning strategy application, which proves that compensation strategy is popular, and emotion strategy attracts little attention.

\section{CONCLUSIONS}

From the above analysis, the paper summarizes the following conclusions.

For the students with visual learning style, visual learning style has important relationship with compensation strategy, emotion strategy, total score and reading score. And cognitive strategy and words score, compensation strategy and total score, compensation strategy and auditory score, compensation strategy and reading score, metacognitive strategy and writing score, and emotion strategy and reading score has close relationship.

For auditory learners, there is close relationship between auditory learning style and metacognitive strategy, social strategy and listening score. And auditory learning style and words score, cognitive strategy and words score, compensation strategy and listening score, compensation strategy and writing score, metacognitive strategy and listening score, and social strategy and listening score has important relationship.

For the learners with tactile learning style, tactile learning style and cognition strategy, compensation strategy and writing score has great relationship. And there is close relationship between cognitive strategy and reading score, compensation strategy and reading score, compensation strategy and words score, metacognitive strategy and reading score, and writing score and social strategy.

The paper researches perceptual learning style of students, application of learning strategies and the relevant achievements, but the research results may be limited, and need to be perfected in the researches in the future.

\section{REFERENCES}

[1] Coffield, F. et al, Learning styles and pedagogy in post-16 learning Learning and Skills Research Center, www.LSRC.AC.UK, 2004.

[2] Liu Ping, Investigation on learning style of non-English major university students, Sino-US English Teaching, 2005(2): 35-38.

[3] Cheng Xiaotang, Zheng Min, English learning strategy, Beijing: Foreign Language Teaching and Research Press, 2002.

[4] Li Li, Chen Zhi'an, Jiang Yuhong, Strategy $\cdot$ style attributionlearning English, Shanghai : Shanghai Foreign Education Press, 2006. 